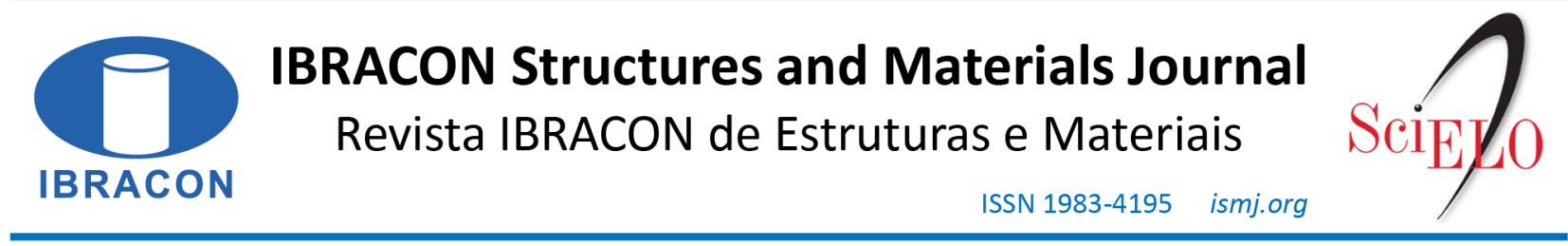

ORIGINAL ARTICLE

\title{
Ultrasonic investigation on the effectiveness of crack repair in concrete
}

\section{Investigação ultrassônica da eficácia do reparo de fissuras no concreto}

\author{
Fabio Caon de Souza ${ }^{\mathrm{a}}$ \\ Roberto Caldas de Andrade Pinto ${ }^{\mathrm{a}}$
}

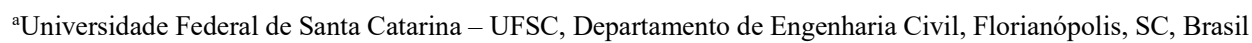

Received 20 December 2018 Accepted 17 February 2020

\begin{abstract}
The crack injection technique using epoxy systems is usually performed in the services of rehabilitation of surface cracks in concrete structures. The evaluation of the injection process can be done by the removal of cores, which is a destructive test not able to evaluate the entire structure. Alternatively, the use of nondestructive testing, specifically those based on the propagation of stress waves can provide information on the effectiveness of injection services. Even though the time-of-flight technique which provides the ultrasonic pulse velocity is the most common parameter used in concrete evaluation, the ultrasound waveform energy-related parameters can be used to indicate if crack was fully filled. The energy of the ultrasound signal depends on the propagated travel path, which differs when the crack is not filled. This paper presents the results of an experimental program with artificial surface cracks filled with epoxy in different depth fractions. Two types of epoxy were used. It was observed that the ultrasound waveform energy-parameters were able to detect repair effectiveness.
\end{abstract}

Keywords: ultrasound, nondestructive methods, energy related parameters, crack repair.

Resumo: Os serviços de reabilitação de fissuras superficiais em estruturas de concreto são normalmente realizados com a técnica de injeção utilizando sistemas epóxi. A avaliação do processo de injeção pode ser feita pela retirada de testemunhos, considerado um teste destrutivo, que não é capaz de avaliar a estrutura com completo. Alternativamente, a utilização de ensaios não destrutivos, especificamente os baseados na propagação de ondas de tensão podem fornecer informações sobre a eficácia dos serviços de injeção. Embora a utilização do tempo de propagação de uma onda ultrassônica, que fornece a velocidade do pulso ultrassônico, seja o parâmetro mais comumente utilizado na avaliação de estruturas de concreto, os parâmetros relacionados à energia da onda de ultrassom podem ser usados para indicar se a fissura foi totalmente preenchida. A energia do sinal de ultrassom depende do caminho de percurso propagado, que difere quando a fissura não está completamente preenchida. Este artigo apresenta os resultados de um programa experimental com fissuras superficiais induzidas preenchidas com epóxi em diferentes frações de profundidade. Dois tipos de epóxi foram usados. Observou-se que os parâmetros de energia da onda de ultrassom foram capazes de detectar a eficácia do reparo.

Palavras-chave: ultrassom, métodos não destrutivos, parâmetros de energia ultrassônica, reparo de fissuras.

How to cite: F. C. Souza and R. C. A. Pinto, "Ultrasonic investigation on the effectiveness of crack repair in concrete," Rev. IBRACON Estrut. Mater., vol. 13, no. 5, e13508, 2020, https://doi.org/10.1590/S1983-41952020000500008

\section{INTRODUCTION}

Cracks often occurs in concrete structures because of tensile stresses as well as some degradation mechanisms such as repeated loading, chemical attacks, drying shrinkage, among others. While surface opening cracks affect the aesthetics of the concrete surface, they may also compromise the durability and safety of the structure. In such latter case, there is a need to restore structure integrity. 
A successful crack repair procedure should account for its cause and geometric characteristics [1]. For example, when injection of synthetic resins is used as repair procedure, the correct application and selection of pump pressure depend on the crack width and depth. The main purpose of this repair method is to completely fill the crack, and thus to connect structurally the concrete on both sides of the crack opening [2].

The bond between concrete and the injection material is overly critical. A suitable bond should restore the original stiffness of the material and prevent penetration of water and degrading agents [3].

The effectiveness of the repair can be assessed by taking cores, which is not always able to analyze the complete structure, since it is not used in large scale. Alternatively, the use of a non-destructive test that verifies crack filling ensures efficiency and quality of the rehabilitation technique.

Nondestructive testing (NDTs) can provide support in making decisions for the diagnosis of a structure. According to Hellier [4], NDTs have experienced significant growth in innovation over the last 25 years, playing an important role in minimizing damages in concrete structures.

Quality control, structural evaluation, maintenance and increasing service life have become important issues in the construction industry in recent years. Nondestructive testing has become increasingly essential for the assessment of the integrity of concrete structures [5].

The use of stress wave propagation methods such as ultrasound allows one to indirectly evaluate the cracking process in a convenient and fast approach. The analysis of variations in the ultrasound pulse velocity (UPV) has been successfully applied in the inspection of concrete structures [6]. There are several examples of such technique in the detection and visualization of non-uniformities within the concrete member [7] and in the estimation of depth of surface opening cracks [8] among other applications.

Using the indirect method of transmission, the travel path of an ultrasonic pulse suffers deviation in the presence of surface opening cracks, leading to larger time-of-flight and thus smaller apparent pulse velocities as compared to a travel path in a sound material [6].

The reflection coefficient of a normal incident stress wave on an interface of different materials can be described by the difference of the acoustic impedance of the materials, as expressed by Equation 1 [9].

$$
R=\frac{Z_{2}-Z_{1}}{Z_{2}+Z_{1}}
$$

Where $R$ is the reflection coefficient for normal incidence, $Z_{2}$ and $Z_{1}$ are the acoustic impedances of materials 2 and 1 , respectively. According to Krautkrämer and Krautkrämer [10], the acoustic impedance of air is $413 \mathrm{~kg} / \mathrm{m}^{2} . \mathrm{s}$, much lower than the value for concrete 6.9 to $10.4 \times 10^{6} \mathrm{~kg} / \mathrm{m}^{2} . \mathrm{s}$ [11]. Therefore, there is no transmission through an air-filled crack, with smaller values of UPV recorded.

However, in the study carried out by Carelli [12] for plastic shrinkage cracking, it was found that the ultrasonic pulse velocity sensitivity is significantly lower than those of the other waveform parameters such as amplitude and energy. This finding indicates the importance of signal behavior analysis for a more accurate and efficient evaluation of the cracking condition of the element. It is well recognized that cracking leads to an attenuation of the ultrasonic signal [13]-[15].

When an ultrasonic stress wave collides with an interface formed by materials with different acoustic properties, a portion of the wave energy is dispersed out of the original path while another part undergoes refraction. This results in the reduction of the energy of the scattered waves as they travel through any material [10].

When a surface crack is partially filled due to different acoustic parameters of epoxy and concrete, there is a loss of transmitted energy due to wave reflection in the interface of both materials. However, since there is also refraction in that interface, a portion of the stress wave maintains its travel path, and thus the time-of-flight between transducers positioned on either side of the crack tip would not change significantly. Consequently, this probable reduction on the wave energy would be detected by possible variation on the UPV.

Aggelis et al. [16] found that the increase in epoxy filling percentage in concrete cracks generates an increase in the signal amplitude value. The waveform amplitude showed greater sensitivity to subsurface cracks as compared to UPV, according to Aggelis et al. [17].

This paper presents the results of an experimental program with artificial surface cracks of various depths filled with epoxy in different depth fractions. Two types of epoxy were used. It was observed that the ultrasound waveform energy parameters were able to verify repair effectiveness. There was an observed increase in the waveform amplitude and energy with increasing crack filling. 


\subsection{Ultrasonic waveform parameters}

Figure 1 shows a typically ultrasonic waveform in a concrete specimen.

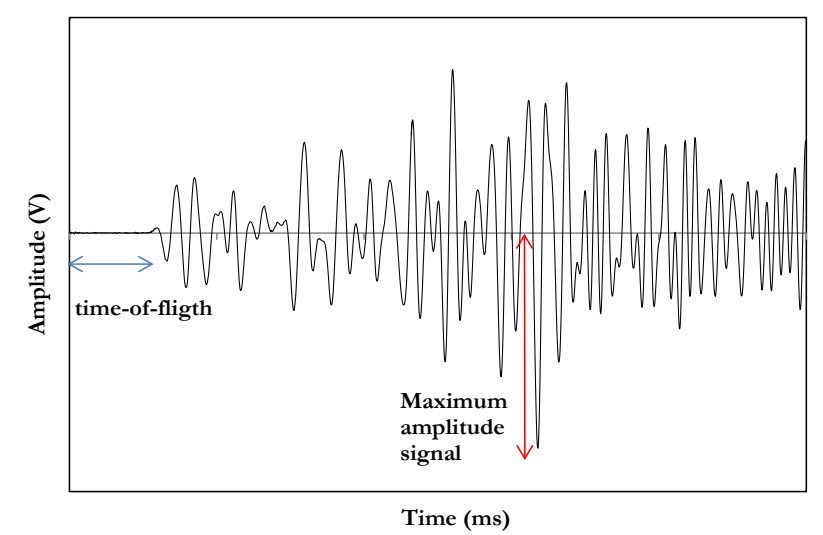

Figure 1. Typical waveform

The time-of-flight parameter is the time observed from the initial stress wave propagation until it reaches the receiving transducer, which would yield the UPV; the maximum amplitude and the waveform energy can also be gathered by the waveform.

When ultrasound is being used to evaluate a concrete structure, it is common to use the ultrasound pulse velocity (UPV) to assess the concrete structure. UPV is related to the time-of-flight between two transducers placed at a known distance. Thus, there is no need to obtain information about the whole waveform.

The maximum amplitude is recorded as the maximum value of the amplitude of the waveform, regardless when it occurred, and therefore represents only a discrete point of the whole signal. The energy of the waveform, on the other hand, accounts for the whole amplitude signal. It can be calculated from the rectified amplitude signal (with absolute amplitude values) according to Equation 2 [15], [18].

$$
E=\int_{0}^{t_{i}}|A(t)| d t
$$

where:

$\mathrm{A}(\mathrm{t})$ - signal amplitude in time $\mathrm{t}$;

$t_{i}$ - end of time window fixed in the experiments.

The ultrasonic waveform parameters used in this study were the time-of-flight, the maximum amplitude and total energy. The total energy was calculated from Equation 2 considering the acquired signal up to $5000 \mu$ s. This upper limit value was chosen since there were no observed signal amplitude variations for times greater than $5000 \mu$ s.

\section{MATERIALS AND EXPERIMENTAL PROGRAM}

Nine concrete prisms with artificially induced surface cracks of different depths and thicknesses were cast. The cracks were repaired in two stages with two types of epoxy. Initially, the crack was partially filled with epoxy, later they were completely filled.

Two series of concrete prisms with artificially induced surface cracks of different depths and thicknesses were cast. Prisms geometry was defined to allow ultrasound estimation of actual crack depth according to a method previously defined [8]. Therefore, prism length was fixed at $800 \mathrm{~mm}$; the width value was fixed at $200 \mathrm{~mm}$ and the height was fixed at $150 \mathrm{~mm}$, except in cases of crack depths of 150 and $220 \mathrm{~mm}$, in which prism height was $300 \mathrm{~mm}$. Series 1 consisted of 4 prisms of $200 \times 150 \times 800 \mathrm{~mm}$ with vertical cracks of 25, 50, 75, and $100 \mathrm{~mm}$ of depth, and two concrete prisms of $150 \times 300 \times 800 \mathrm{~mm}$ with vertical cracks of $150 \mathrm{~mm}$ and $220 \mathrm{~mm}$. All these six prisms had crack widths of $6 \mathrm{~mm}$. The second series comprised of concrete prisms of $200 \times 150 \times 800 \mathrm{~mm}$ with vertical cracks of 50,75 and $100 \mathrm{~mm}$ and crack width of $20 \mathrm{~mm}$. Table 1 presents a summary of the geometric characteristics of all the specimens. 
Table 1. Specimens geometry

\begin{tabular}{|c|c|c|c|c|c|}
\hline \multicolumn{2}{|c|}{ Specimen } & \multirow{2}{*}{$\begin{array}{c}\begin{array}{c}\text { Size } \\
\text { (width } \times \text { height } \times \text { length) } \\
\text { in } \mathbf{~ m m}\end{array} \\
250 \times 150 \times 800\end{array}$} & \multirow{2}{*}{$\begin{array}{c}\text { Crack depth (mm) } \\
25\end{array}$} & \multirow{2}{*}{$\begin{array}{c}\text { Crack width (mm) } \\
3\end{array}$} & \multirow{2}{*}{$\frac{\text { Epoxy }}{}$} \\
\hline Series 1 & $\mathrm{~S} 1-25-3$ & & & & \\
\hline & $\mathrm{S} 1-50-3$ & $250 \times 150 \times 800$ & 50 & 3 & A \\
\hline & $\mathrm{S} 1-75-3$ & $250 \times 150 \times 800$ & 75 & 3 & A \\
\hline & $\mathrm{S} 1-100-3$ & $250 \times 150 \times 800$ & 100 & 3 & A \\
\hline & $\mathrm{S} 1-150-3$ & $150 \times 300 \times 800$ & 150 & 3 & A \\
\hline & $\mathrm{S} 1-220-3$ & $150 \times 300 \times 800$ & 220 & 3 & $\mathrm{~A}$ \\
\hline \multirow[t]{3}{*}{ Series 2} & $\mathrm{~S} 2-50-20$ & $250 \times 150 \times 800$ & 50 & 20 & B \\
\hline & $\mathrm{S} 2-75-20$ & $250 \times 150 \times 800$ & 75 & 20 & B \\
\hline & S2-100-20 & $250 \times 150 \times 800$ & 100 & 20 & $\mathrm{~B}$ \\
\hline
\end{tabular}

All cracks were artificially made. During casting, a plate with the specified thickness was placed on the side of the specimen. At approximately six hours after casting, the plate was removed, and the artificial crack formed. Before performing ultrasound measurements, the specimen was rotated $90^{\circ}$. Thus, ultrasound measurements were performed on a flat and smooth surface with any line of testing perpendicular to the crack being at the same level of consolidation.

A Brazilian composite cement with pozzolan addition up to $14 \%$ in mass, ASTM C 33 natural fine aggregate and coarse aggregate with maximum aggregate size of $19 \mathrm{~mm}$ were used. Concrete compressive strength was evaluated after 28 days. The results indicated a compressive strength of $20 \mathrm{MPa}$.

The ultrasound measurements were performed with a commercially available equipment using $54 \mathrm{kHz}$ central frequency p-wave transducers with an acquisition frequency of $2 \mathrm{MHz}$. A coupling agent was previously applied to the concrete surface on which the $50 \mathrm{~mm}$ diameter transducers would be placed.

After 28 days of casting, ultrasound time-of-flight was used to estimate the actual crack depth. The procedure presented by Pinto et al. [8], called Method A was used. In this method, as shown in Figure 2, the transducers are placed in at least four equidistant locations from the surface opening crack along a chosen line $\left(\mathrm{x}_{1}\right.$ to $\left.\mathrm{x}_{4}\right)$.

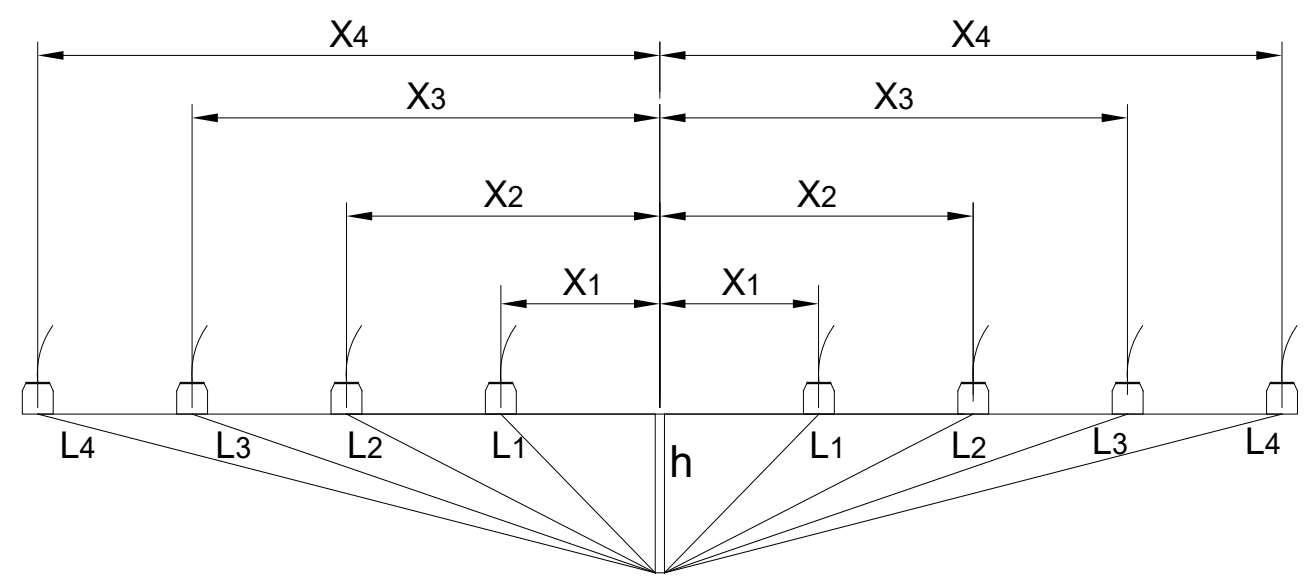

Figure 2. Transducer arrangements for graphically-based Method A [8]

Time-of-flight readings are performed at each transducer arrangement. The crack penetration depth, $h$, is obtained by plotting the square of the distance between the transducers to the crack with the square of the time recorded. The slope of the best straight line is proportional to the UPV while its intersection is proportional to the crack depth. Table 2 presents crack penetration depth estimates obtained from Method A [8]. The highest error was below 6\%, which is below the $15 \%$ error reported by Bungey and Grantham [6]. 
Table 2. Estimated crack depths by Method A [8]

\begin{tabular}{|c|c|c|c|}
\hline Specimen & Crack depth (mm) & Estimated crack depth (mm) & Error (\%) \\
\hline S1-25-3 & 25 & 24.4 & 4.0 \\
\hline S1-50-3 & 50 & 49.2 & 2.0 \\
\hline S1-75-3 & 75 & 72.1 & 4.0 \\
\hline S1-100-3* & 100 & - & - \\
\hline S1-150-3 & 150 & 144.6 & 3.7 \\
\hline S1-220-3 & 220 & 207.7 & 5.9 \\
\hline $\mathrm{S} 2-50-20$ & 50 & 49.0 & 2.0 \\
\hline $\mathrm{S} 2-75-20$ & 75 & 74.0 & 1.3 \\
\hline S2-100-20 & 100 & 106.1 & 5.8 \\
\hline
\end{tabular}

* specimen broke during test

The resin application was carried out in two stages, as shown in Figures 3 and 4 . The first application was performed on the crack surface to simulate partial filling, as can be seen in Figure 3.

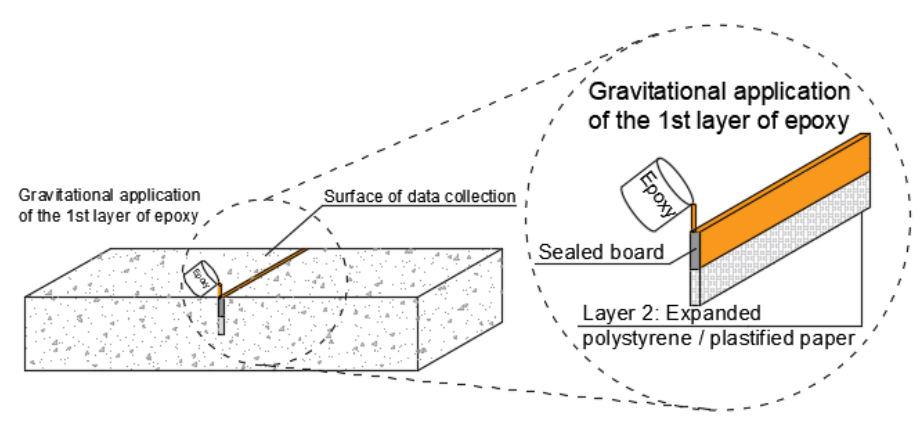

Figure 3. $1^{\text {st }}$ stage of resin application

The cracks were filled with epoxy by gravity. Expanded polystyrene and plasticized paper were used to prevent epoxy penetration for prisms with crack width of $20 \mathrm{~mm}$ and $3 \mathrm{~mm}$, respectively. To prevent leakage, the edges of the prisms were sealed. The procedure for preparing the resins followed the manufacturer's recommendations with curing time between each application of 7 days.

In the first stage, after cleaning the crack with compressive air, expanded polystyrene or plasticized paper layer was applied along with sealing of the edges of the prisms to ensure that the resin would partially fill the crack, as can be seen in Figure 3. After a curing period of 7 days, ultrasound measurements were taken with transducers placed on opposite sides of the crack at $100 \mathrm{~mm}$. A mass of $8.55 \mathrm{~kg}$ was placed on the top of the $50 \mathrm{~mm}$ diameter transducers, and consequently a constant pressure of $0.047 \mathrm{MPa}$ was applied on the transducers when the waveforms were acquired.

Then, epoxy was applied to complete filling the cracks, as can be seen in Figure 4.

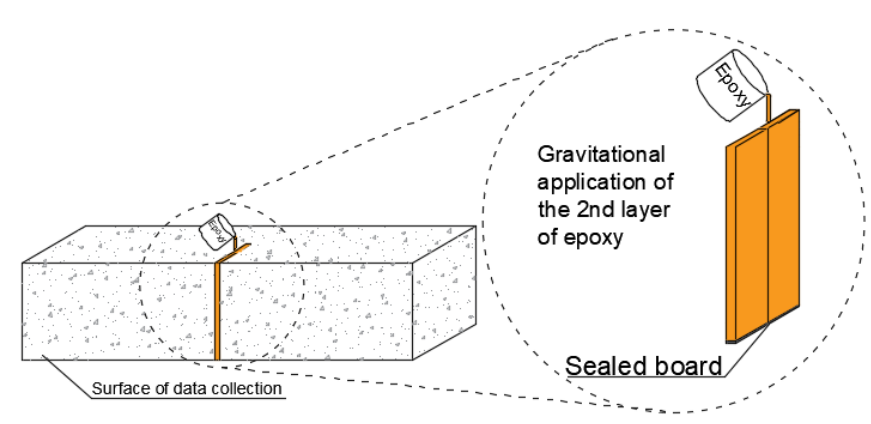

Figure 4. $2^{\text {nd }}$ stage of resin application 
After 7 days, new ultrasound measurements were performed with transducers again placed at $100 \mathrm{~mm}$ from the crack tip. Figure 5 shows both stage of resin application.

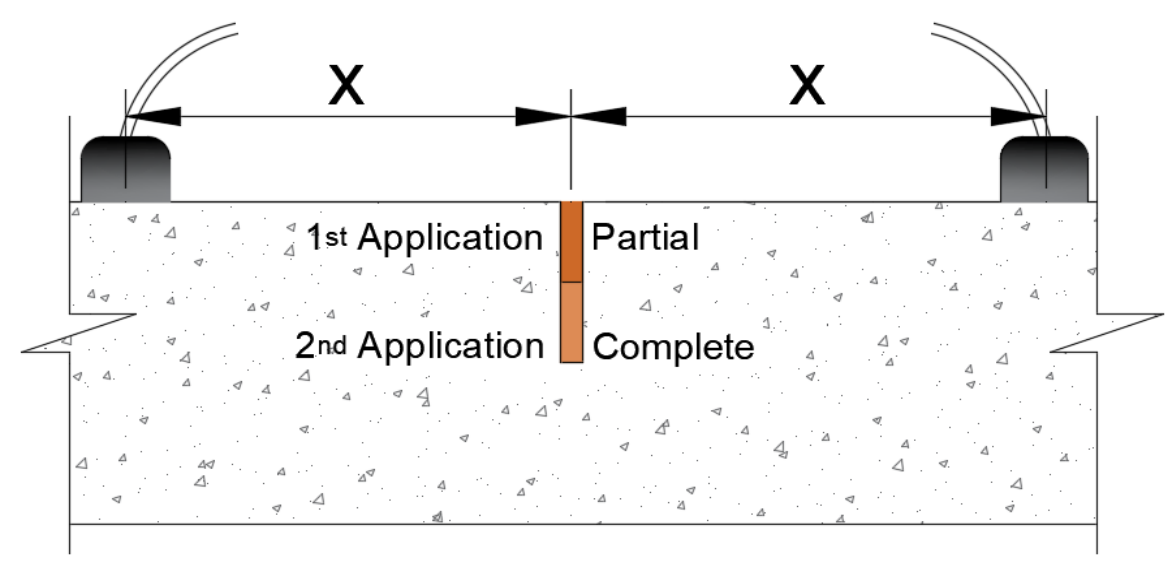

Figure 5. Stages of application of epoxy repair

Two different types of epoxy were chosen. A low-viscosity epoxy, called Epoxi A, was used for prisms of Series 1 with crack width of $3 \mathrm{~mm}$; while a medium-viscosity epoxy, called Epoxi B, was used for prisms of Series 2 with crack width of $20 \mathrm{~mm}$. Concrete and epoxy acoustic characteristics are presented in Table 3.

Table 3. Concrete and epoxy acoustic characteristics.

\begin{tabular}{cccc}
\hline Material & density $\left(\mathbf{k g} / \mathbf{m}^{\mathbf{3}}\right)$ & UPV (m/s) & $\begin{array}{c}\text { Acoustic impedance } \\
\left(\mathbf{k g} / \mathbf{m}^{2} \cdot \mathbf{s}\right)\end{array}$ \\
\hline Concrete & 2340 & 4070 & $9.5210^{6}$ \\
\hline Epoxy A & 1100 & 2513 & $2.7610^{6}$ \\
\hline Epoxy B & 1710 & 2808 & $4.8010^{6}$ \\
\hline
\end{tabular}

\section{RESULTS AND DISCUSSIONS}

Figure 6 presents the waveforms obtained from ultrasound readings for S1-150-3 specimen with unrepaired, partially repaired and fully repaired crack. Figure 6 relates the transmission time with the percentage of the input voltage $(500 \mathrm{~V})$.

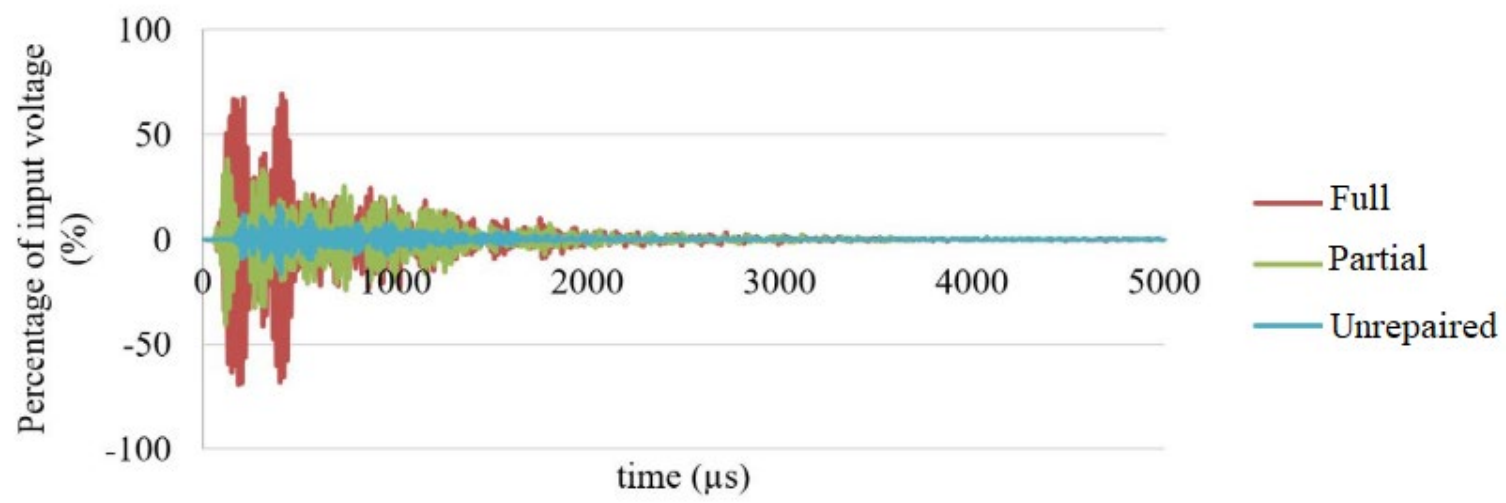

Figure 6. Waveforms from specimen S1-150-3 
The signals were superimposed so that each color represents the stage of application of the epoxy. Similar waveforms were obtained from other readings.

There was an observed increase in the amplitudes as the crack was being repaired. From each waveform, time-offlight, maximum signal amplitude and the total accumulated energy defined as the propagation energy up to $5000 \mu \mathrm{s}$ were recorded. Figures 7 to 9 present the obtained values for all specimens.

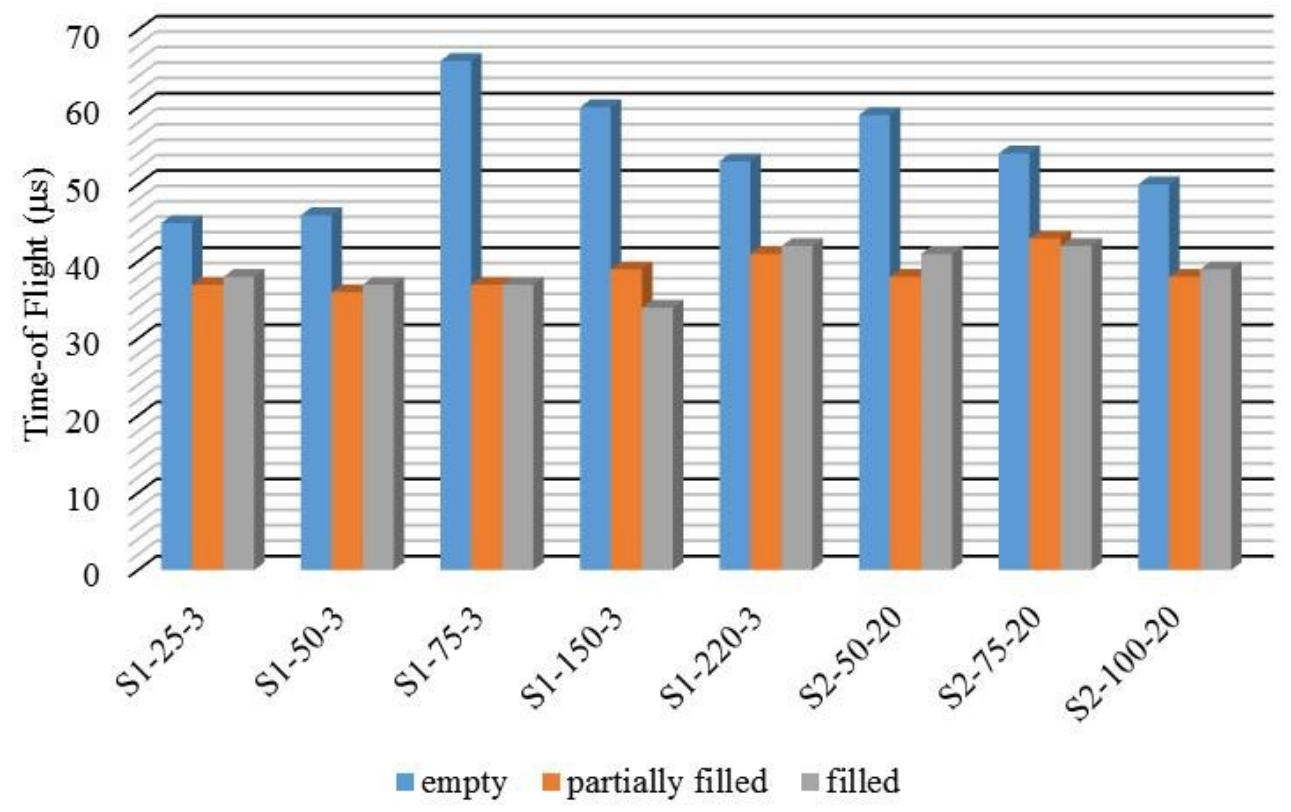

Figure 7. Time-of-flight between transducers $200 \mathrm{~mm}$ apart

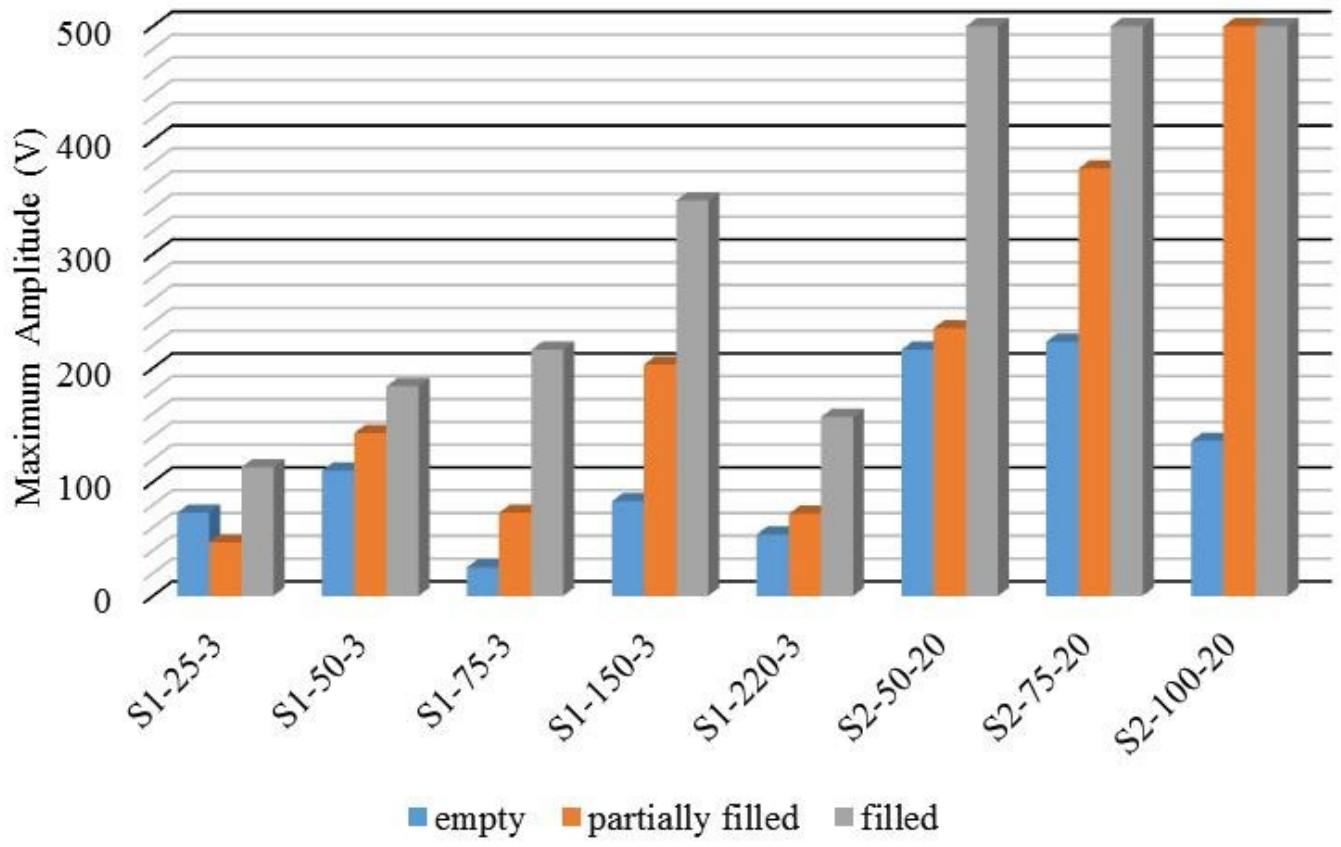

Figure 8. Maximum amplitude values 


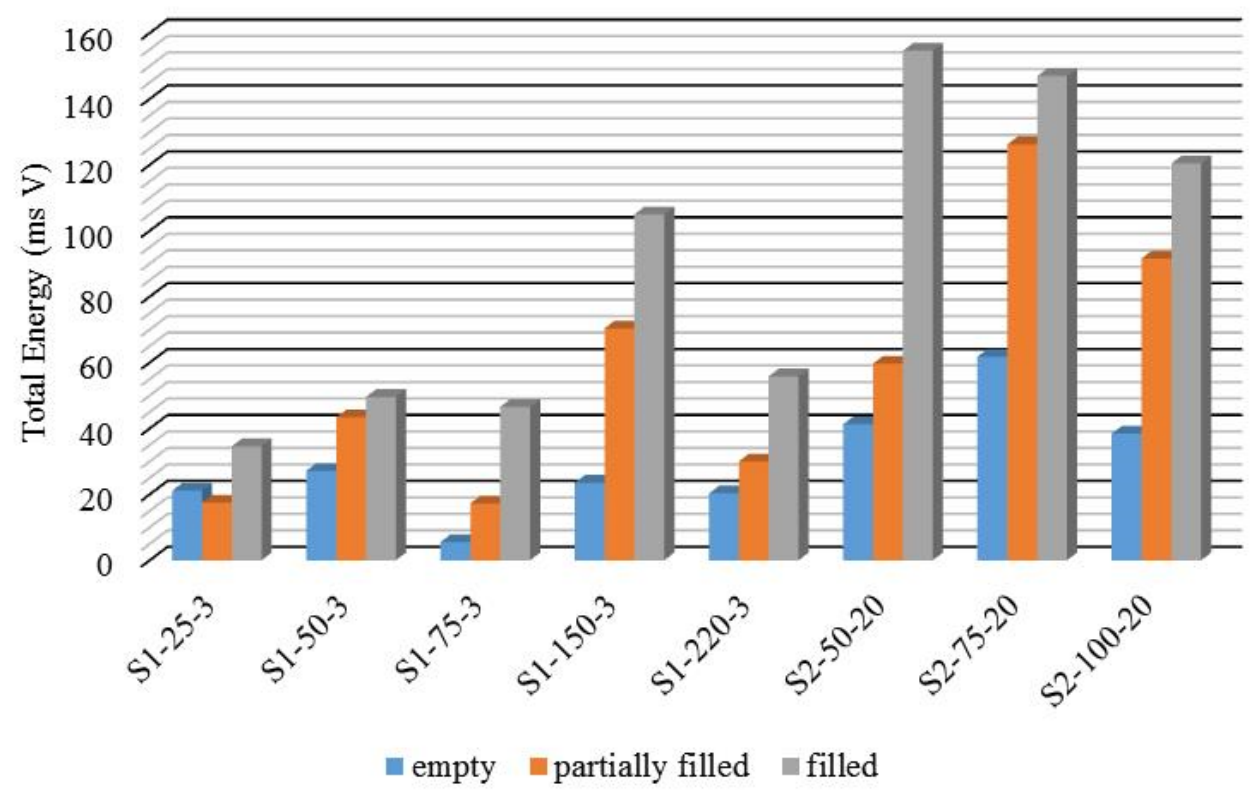

Figure 9. Total energy values

Figure 7 shows that there was not a significant difference between the time of flight when the crack was partially filled or completely filled, and therefore no significant changes on the UPV was recorded. As can be seen in Figure 7, the difference between time-of-flight values for the partially filled and completely filled specimens did not vary more than $3 \mu \mathrm{s}$, with absolute values ranging from $34 \mu \mathrm{s}$ to $43 \mu \mathrm{s}$. However, much higher differences were observed among an empty crack specimen and when the crack was partially or fully filled. For instance, the time-of-flight recorded for specimen S1-75-3 was $66 \mu$ s when the crack was empty and $37 \mu$ s when it was partially and fully filled. This difference occurred because in the indirect transmission method, even some internal non-homogeneity (such as voids from below the partially filled crack) does not alter the wave propagation path and therefore a decrease in time-of-flight should occur when the crack is partially or fully filled.

On the other hand, as shown in Figures 8 and 9, the waveform parameters, maximum amplitude, and total energy, were sensitive to partial filling. For all specimens, except S1-25-3, there was an increase of energy and amplitude values according to the filling percentage of the crack. A previous research has shown that for small cracks, around $25 \mathrm{~mm}$ in depth, the use of ultrasonic pulse velocity was not able to accurately predict crack depth sizes [19].

In few cases, the maximum amplitude values reached the maximum value of $500 \mathrm{~V}$ before total filling of the crack (specimen S2-150-20). Therefore, this energy-related parameter may not be suitable to identify effectiveness of crack repair in any situation.

The best waveform parameter seems to be the total energy, as can be seen in Figure 9 . The total energy up to $5000 \mu \mathrm{s}$ was able to identify partial filling for all specimens. In all specimens, except S1-25-3 as already discussed, the total energy values for the partially filled specimens were between the values recorded when the crack was empty and when it was completely filled with epoxy. Such an observed increase in total energy as the crack was being filled is due to the higher acoustic impedance of epoxy as compared to air. According to Equation 1, one could conclude that when the crack is being filled with epoxy, less wave reflections at the interface occurs, and therefore higher wave amplitudes arrive at the receiver transducer. Therefore, the total energy should be increase.

From the above discussion, it can be noticed that only relying on the time-of-flight would not guarantee to verify the effectiveness of crack filling. The time-of-flight parameter is an indeed good estimator of crack depth, but to verify if a crack repair service was fully effective, it is recommended that the ultrasonic waveform is acquired.

The ultrasonic waveform indicates changes in the stress wave due reflection and refraction that occurs in any interface of materials with different acoustic properties. For the prisms tested here, an interface of concrete-epoxy would alter the waveform but not the time-of-flight. Wave refraction occurs allowing to maintain a travel path given by the distance between transducers. Thus, by relying solely on time-of-flight, or UPV, one would not be able to detect if a 
surface crack was fully filled. However, by analyzing the whole waveform and its energy-related parameters such as amplitude and total energy, changes in crack filling percentages can be detected.

\section{CONCLUSIONS}

The aim of this work was to analyze the sensitivity of the parameters associated to the ultrasonic signal in the evaluation of the integrity of the epoxy system filling in surface crack openings in concrete structures.

After epoxy has been applied to repair the artificially induced cracks, it was verified that the time-of-flight was not a sensitive parameter for different filling percentages, since there was not an observed change when the crack was partially or fully filled.

On the other hand, the total energy and maximum amplitude of the signal were shown to be sensitive parameters for prisms with crack depths greater than $25 \mathrm{~mm}$. As the filling increased, the higher their values were in the signal.

In summary, the parameters of maximum amplitude and total energy of ultrasonic waveform obtained from transducers placed at $100 \mathrm{~mm}$ distance of the crack tip were able to detect partial filling of cracks greater than $25 \mathrm{~mm}$.

\section{ACKNOWLEDGEMENTS}

The authors would like to acknowledge CNPq (National Council for Scientific and Technological Development) for financial assistance; to company Pedrita for the supply of aggregates and to GPEND/LEE/UFSC where the research was developed.

\section{REFERENCES}

[1] American Concrete Institute. ACI Committee 224, Causes, Evaluation, and Repair of Cracks in Concrete Structures, ACI 224.1R-07, 2007.

[2] American Concrete Institute. Crack Repair by Gravity Feed with Resin, ACI E706, ACI RAP-2, 2009.

[3] K. Minoru, K. Toshiro, U. Yuichi, and R. Keitetsu, "Evaluation of bond properties in concrete repair materials," J. Mater. Civ. Eng., vol. 13, no. 2, pp. 98-105, 2001.

[4] C. Hellier, Handbook of On-destructive Evaluation, 2nd ed. New York, NY, USA: McGraw-Hill Education, 2012, , pp. 7.11-7.12.

[5] G. Karaiskos, A. Deraemaeker, D. G. Aggelis, and D. V. Hemelrijck, "Monitoring of concrete structures using the ultrasonic pulse velocity method," Smart Mater. Struct., vol. 24, no. 11, pp. 113001, 2015.

[6] J. H. Bungey and M. G. Grantham, Testing of Concrete in Structures, 4th ed. London: Blackie Academic \& Professional, 2006, 339 p.

[7] L. P. Perlin and R. C. A. Pinto, "Ultrasonic tomography in concrete," Ibracon Struct. Mater. J., vol. 6, no. 2, pp. $246-269,2013$.

[8] R. C. A. Pinto, A. Medeiros, I. J. Padaratz, and P. B. Andrade, "Use of ultrasound to estimate depth of surface opening cracks in concrete structures," E-J. Nondestruct. Test. Ultrason., pp. 1-11, 2010.

[9] L. E. Kinsler, A. R. Frey, A. B. Coppens, and J. V. Sanders, Fundamentals of Acoustics, 4th ed. New York: John Wiley \& Sons, 2000.

[10] J. Krautkrämer and H. Krautkrämer, Ultrasonic Testing of Materials, 4th ed. Berlin: Springer-Verlog, 1990.

[11] N. J. Carino, "Stress wave propagation methods," in Handbook on Nondestructive Testing of Concrete, 2nd ed., V. M. Malhotra and N. J. Carino, Ed., Boca Raton: CRC Press, 2004.

[12] J. M. Carelli, “Análise do comportamento de ondas ultrassônicas em elementos fissurados de concreto e argamassa,” M.S. thesis, Univ. Fed. Santa Catarina, Florianópolis, 2014.

[13] W. Suaris and V. Fernando, "Detection of crack growth in concrete from ultrasonic intensity measurements," Mater. Struct., vol. 20, no. 3, pp. 214-220, 1987.

[14] S. F. Selleck, E. N. Landis, M. L. Peterson, S. P. Shah, and J. D. Achenbach, "J. D., "Ultrasonic investigation of concrete with distributed damage," ACI Mater. J., vol. 95, no. 1, pp. 27-36, 1998.

[15] T. Shiotani and D. G. Aggelis, "Wave propagation in cementitious material containing artificial distributed damage," Mater. Struct., vol. 42, no. 3, pp. 377-384, 2009.

[16] D. G. Aggelis, T. Shiotani, and D. Polyzos, "Characterization of surface crack depth and repair evaluation using Rayleigh waves," Cement Concr. Compos., vol. 31, no. 1, pp. 77-83, 2009.

[17] D. G. Aggelis, E. Leonidou, and T. E. Matikas, "Subsurface crack determination by one-sided ultrasonic measurements," Cement Concr. Compos., vol. 34, no. 2, pp. 140-146, 2012. 
[18] A. V. Hauwert, F. Delannay, and J. F. Thimus, "Cracking behavior of steel fiber reinforced concrete revealed by means of acoustic emission and ultrasonic wave propagation," ACI Mater. J., vol. 96, no. 3, pp. 291-296, 1999.

[19] P. B. Andrade, "Estimativa da profundidade de fendas no concreto através da utilização do ultrassom e do eco-impacto,” M.S. thesis, Univ. Fed. Santa Catarina, Florianópolis, 2010.

Author contributions: FCS: conceptualization, methodology, data evaluation, writing; RCAP: supervision, writing.

Editors: Vladimir Guilherme Haach, José Luiz Antunes de Oliveira e Sousa, Guilherme Aris Parsekian. 